\title{
COMMINUTION OF DIFFERENT GRANITE SAMPLES OF SOUTH EASTERN DESSERT OF EGYPT
}

\author{
Mahmoud M. Ahmed ${ }^{1}$ and Gamal Y. Boghdady ${ }^{2}$ \\ ${ }^{1}$ Associate Professor at the Mining and Metallurgical Engineering Department, \\ Faculty of Engineering, Assiut University, Assiut 71516, Egypt \\ E-mail: mamoah2000@yahoo.com.au \\ ${ }^{2}$ Assistant Professor at the Mining and Metallurgical Engineering Department, \\ Faculty of Engineering, Assiut University, Assiut 71516, Egypt
}

\section{(Received October 22, 2008 Accepted January 22, 2009)}

Granite is commonly and widely occurring type of intrusive felsic igneous rock. Granite particles, obtained from comminution and concentration processes, may be used for many industrial applications. For example, granite chippings and cullet are mixing with the red mud to produce glass-ceramics materials via melting and crystallization [1]. Granites with suitable lithium grades are added to the glass and ceramics industries [2]. Feldspar in granite rock is largely used as raw material in the ceramic and glass industry [3]. The aim of current work is to study and compare the comminution characteristics of different granite samples obtained from South Eastern desert of Egypt.

The samples under study were classified according to their compositions as different types of granite, i.e. diorite, tonalite, monzogranite and granodiorite. The main constituents of samples are plagioclase, quartz, and orthoclase. The results assure that tonalite has the highest ability of comminution while monzogranite has the lowest compared with other samples. The percent of quartz has no effect on the comminution of tonalite and monzogranite. Crushing and grinding processes increased from monzogranite through granodiorite, diorite to tonalite as the plagioclase percent increased. The percent of quartz has a significant effect on the crushing of diorite and granodiorite. Although the difference in quartz percent did not exceed $12.3 \%$, the difference in their values of $x_{50}$ reached to $278.6 \mu \mathrm{m}(36.1 \%)$. The difference was about $354.6 \mu \mathrm{m}$ (31.6\%) between their values of MPSD. The percent of quartz has no significant effect on the grinding of these two materials. Although the difference in quartz percent reached to $12.3 \%$, the difference in their values of $x_{50}$ did not exceed $4.6 \mu \mathrm{m}(2.1 \%)$. The difference between their values of MPSD was about $16.5 \mu \mathrm{m}(5.0 \%)$. The results revealed also that the percent of quartz has no significant effect on the grinding of all materials understudy. The comminution of different studied granites decreased with increasing the compressive strength and decreasing the abrasion.

KEYWORDS: granite, tonalite, granodiorite, monzogranite, diorite, Rosin-Rammler model, crushing, grinding, median of particle size, mean of particle size distribution 


\section{NOMENCLATURE:}

c the size of particles which is corresponding to $63.2 \%$ cumulative weight distribution undersize obtained from RR model

$m$ a characteristic constant of the material under analysis obtained from RR model giving a measure of steepness of cumulative weight undersize distribution curve

MPSD mean of a particle size distribution

$R^{2} \quad$ coefficient of correlation

$x_{50}$ median or the size which corresponds to $50 \%$ cumulative weight passed

\section{INTRODUCTION}

Granite is commonly and widely occurring type of intrusive felsic igneous rock. Granites have usually white, grey or buff (pink) colours. They are occasionally medium to coarse grained, with some individual crystals, larger than the groundmass forming a rock, known as porphyry.

Granite sometimes occurs in circular depressions surrounded by a range of hills, formed by the contact metamorphism. Granitoids constitute $40 \%$ of the Proterozoic shield rocks in Egypt. They are considered as an important rock group that covers vast area of the Arabian-Nubian shield. They have been classified by deferent ways. Akaad and El-Ramly [4] divided the granite into two groups, i.e. the older grey granites, and the younger intrusive red and pink granites. El-Shazly [5] divided the Egyptian granites into syn-orogenic plutonites, late-orogenic plutonites and finally post-orogenic plutonites. El-Gaby and Habib [6] classified the Egyptian granite into two types, i.e. early syn-orogenic granites of tonalite to granodiorite composition, and late orogenic calc-alkaline to per-alkaline granite series which comprising the alkaline to per-alkaline pink and red granites. El Shatoury et al. [7] classified the Egyptian granite as the old or syn-orogenic granitoids (Gr. A), the young or post orogenic (Gr. B), and the youngest alkali granite (Gr. C). El Gaby et al. [8] classified the Egyptian granite on the basis of field work, petrographical studies, and remote sensing, into three distinct types $(\mathrm{G} \alpha, \mathrm{G} \beta$ and $\mathrm{G} \gamma)$.

Many researchers have studied the breakage and beneficiation of granites [1,914]. Granite grinding tests, under dry and wet conditions, were performed to assess the influence of abrasive particle size to the wear behavior of martensitic high-chromium white cast iron mill balls. It was demonstrated that the highest ball wear rates were observed for fine granite grinding under dry $(120 \mathrm{mg} / \mathrm{cycle})$ and wet $(129 \mathrm{mg} / \mathrm{cycle})$ conditions. The lowest wear rate $(50 \mathrm{mg} / \mathrm{cycle})$ was observed for coarse granite grinding (dry and wet) [10]. An investigation reported by $\mathrm{Xu}$ [9] of the temperatures and energy partition for grinding of granite with a diamond grinding wheel. It was found that about $70 \%$ of the generated energy at the wheel-workpiece interface is transported as heat to the grinding wheel.

The red mud (i.e., shale with high percent of iron) was mixed with granite chippings and cullet to produce glass-ceramics materials via melting and crystallization [1]. 
Amarante [2] described a study conducted on the processing of a spodumene ore occurring as aplite-pegmatitic lodes in granites located in Northern Portugal, in order to obtain lithium concentrates for addition to glass and ceramic bodies. From the treatment of this ore, by flotation and HMS, it was possible to obtain concentrates with lithium grades capable of being used by the glass and ceramics industries. Feldspar present in granite rocks is largely used as raw materials in the ceramic and glass industry [3].

The above literature explains the importance of crushing, grinding, and upgrading of granite. The aim of present work is to study the comminution behavior of different granite samples obtained from Qeft-Qusier road, $100 \mathrm{~km}$ from Fawakheer in South Eastern desert of Egypt.

\section{Modal Analysis and Petrographical Studies of Granite Samples}

Modal analysis, of granite samples studied in this work, was carried out. The different types of Egyptian granites classified petrographically. The final results were listed in Table 1. These data were plotted on the triangular diagram of Qz-Pl-KF of Streckeisen [15] as shown in Fig. 1. From this diagram, it can be revealed that the granite samples are classified into four different types. The first type is called diorite (sample 1), the second one is named tonalite (sample 2), the third type is mentioned by monzogranite (sample 3), and the last composition is granodiorite (sample 4).

Table 1: Compositions of minerals in different granites

\begin{tabular}{|c|c|c|c|c|c|}
\hline \multirow[b]{2}{*}{ Material } & \multicolumn{3}{|c|}{ Composition } & \multirow{2}{*}{$\begin{array}{c}\text { Compressive } \\
\text { strength, } \\
\text { MN/m }^{2}\end{array}$} & \multirow[b]{2}{*}{$\begin{array}{c}\text { Abrasion, } \\
\text { gm } / \mathbf{c m}^{2}\end{array}$} \\
\hline & $\begin{array}{c}\text { Quartz } \\
\%\end{array}$ & $\begin{array}{c}\text { Plagioclase } \\
\%\end{array}$ & $\begin{array}{c}\text { Orthoclase } \\
\%\end{array}$ & & \\
\hline Diorite & 15.8 & 64.9 & 19.3 & 134.2 & 0.0190 \\
\hline Tonalite & 23.6 & 74.8 & 1.6 & 124.3 & 0.0284 \\
\hline Monzogranite & 25.7 & 39.5 & 34.8 & 119.7 & 0.0733 \\
\hline Granodiorite & 28.1 & 62.4 & 9.5 & 106.1 & 0.1055 \\
\hline
\end{tabular}

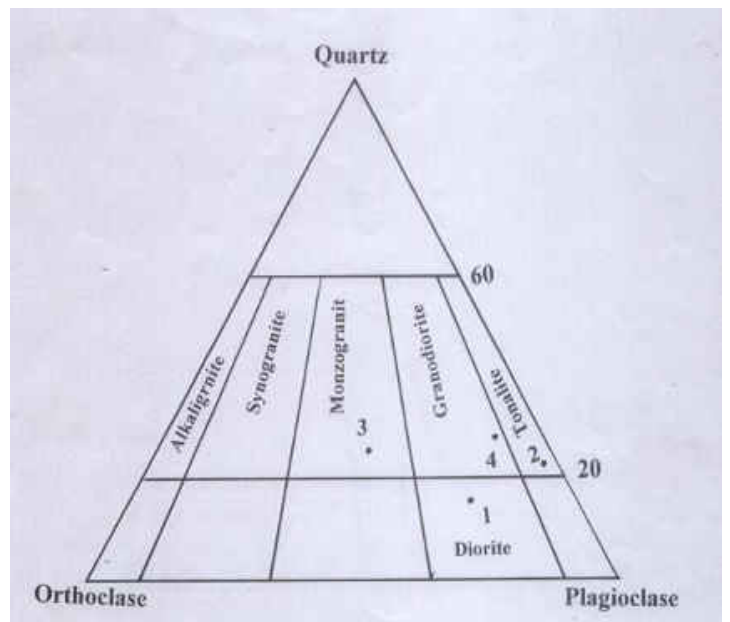

Fig. 1: A triangular diagram of quartz-plagioclase-orthoclase 


\section{Petrographical Description of Granite Samples}

\section{Diorite}

Diorite is a fine to medium grained size. It has a dark gray color and hypidiomorphic texture. Microscopically, it is composed principally of plagioclase, orthoclase, quartz and minor biotite and chlorite as secondary minerals. Iron oxides occur as accessory minerals. The microscopical properties of minerals in diorite are the same as in granodiorite but the percentage of quartz is less than $20 \%$. A photomicrograph of diorite sample is revealed in Fig. 2a.

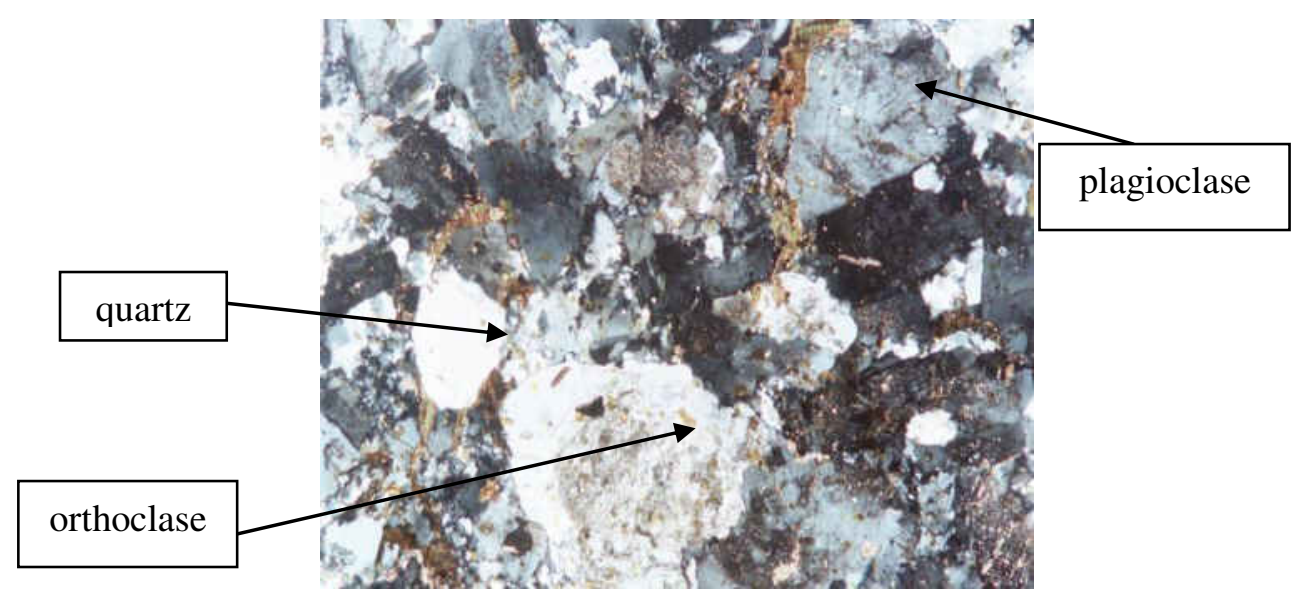

Fig. 2a: A photomicrograph of diorite sample (C.N. x 50)

\section{Tonalite}

Tonalitic granite is a coarse to medium grained size and it has a gray color. Under microscope, it is composed mainly of plagioclase, quartz, and biotite with chlorite as secondary minerals. Sphene, epidote, and iron oxides are found as accessory minerals. Plagioclase has an euhedral to subhedral colorless crystal. It has a white gray in interference color. It is characterized by albite twinning and containing some inclusions from epidote and biotite crystals. Quartz occurs as a filling material into the spaces between the other mineral crystals. Quartz is anhederal crystal, colorless and wavy extension. Biotite occurs as euhedral fiber crystal. It is light brown in color and is altered to chlorite. Chlorite occurs as anhedral crystal. It has light green color with dark green interference color. Epidote is showing as a disseminated colorless fine anhedral crystal with a high interference color. Sphene occurs as colorless euhedral crystal with low interference color. Iron oxides are showing fine euhedral to subhedral crystals. A photomicrograph of tonalite sample is shown in Fig. 2b.

\section{Monzogranite}

Monzogranite is a medium to coarse grained size. It has a pink color and hypidiomorphic texture. Microscopically, it is composed principally of orthoclase, plagioclase, quartz, and biotite and chlorite as secondary minerals. Epidote and iron oxides are found as accessory minerals. A photomicrograph of monzogranite sample is illustrated in Fig. 2c. 


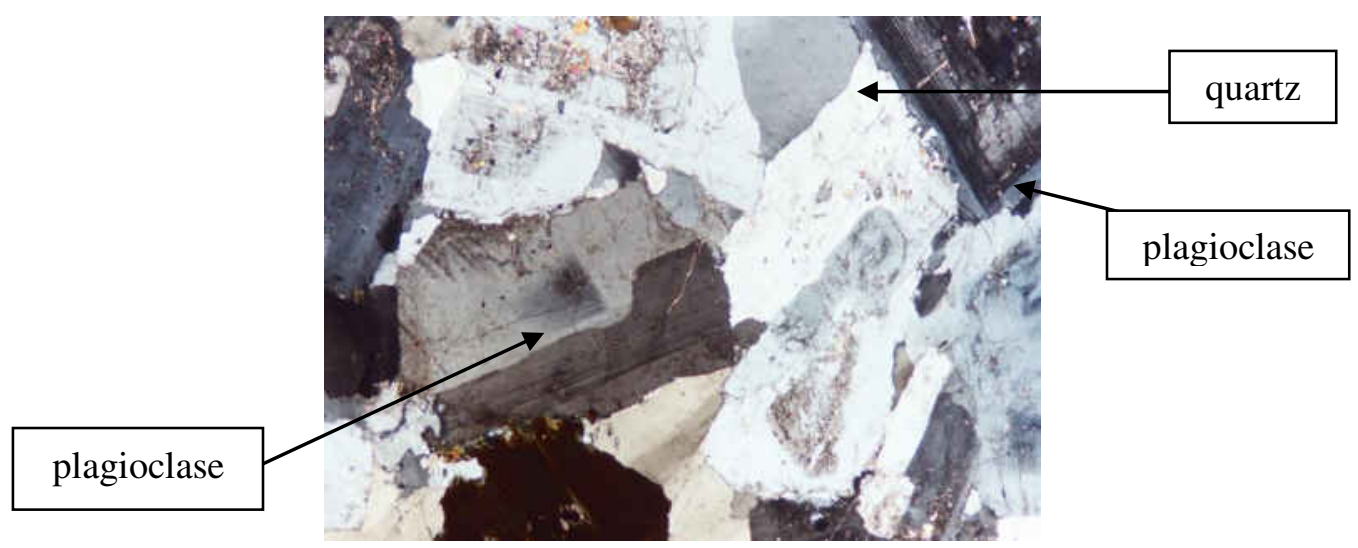

Fig. 2b: A photomicrograph of tonalite sample (C.N. x 25)

\section{Granodiorite}

The granodiorite has inequigranuler crystals. It is a dark gray in color and has porphyretic texture. Under microscope, it is composed principally of plagioclase, orthoclase, quartz and a minor of biotite and chlorite as secondary minerals. Epidote and iron oxides occur as accessory minerals. Orthoclase is represented by a wavy extension. It is characterized as sausuritized or koalinitized and occurs in some orthoclase and microcline. Orthoclase presents as anhedral larger dimension crystals with colorless and low interference color. It is characterized by microperthite texture and some inclusions from plagioclase, biotite, and epidote. Microcline occurs as subhedral crystals, colorless, and is characterized by cross hatching twining and wavy extension. A photomicrograph of granodiorite sample is shown in Fig. 2d.

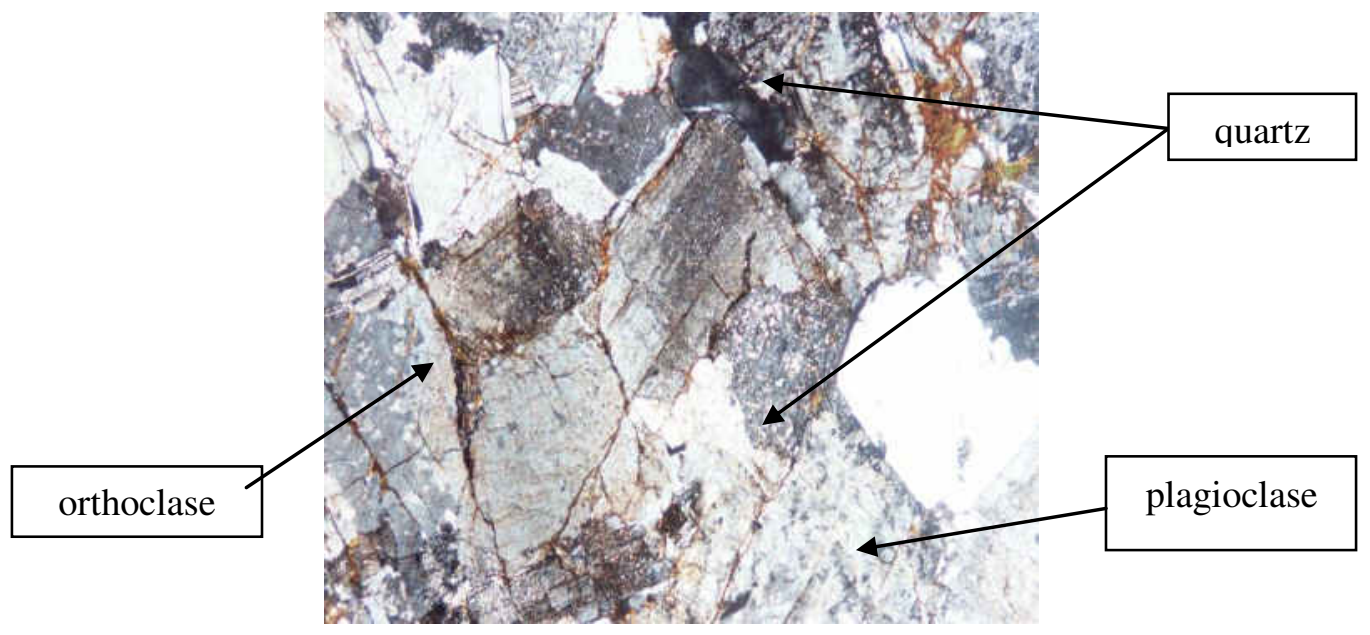

Fig. 2c: A photomicrograph of monzogranite sample (C.N. x 25) 


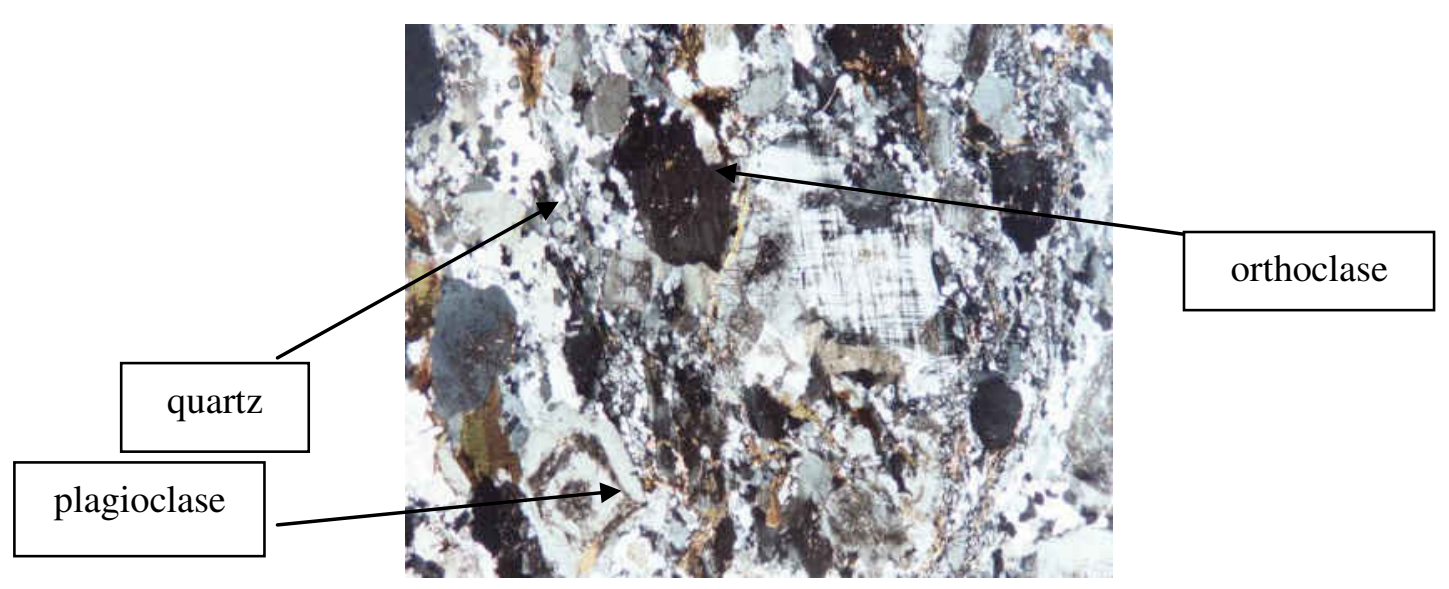

Fig. 2d: A photomicrograph of granodiorite sample (C.N. x 25)

\section{EXPERIMENTAL}

The different granite samples, used in the present work, were obtained from different valleys near the Qeft-Qusier road, $100 \mathrm{~km}$ from Fawakheer in South Eastern dessert of Egypt. The representative samples were split to smaller ones and crushed to minus $3.15 \mathrm{~mm}$ in a closed laboratory jaw crusher. A representative volume $\left(600 \mathrm{~cm}^{3}\right)$ weighing about $950 \mathrm{gm}$ of the crusher product of each sample was ground in a laboratory ball mill having a diameter of $16 \mathrm{~cm}$ and a length of $16 \mathrm{~cm}$. Grinding conditions were as follows: slope of mill $=0^{\circ}$, volume percentage of balls $=42 \%$ of mill volume. This volume represents $1365 \mathrm{~cm}^{3}$. Filling ratio $=90 \%$ of voids volume between balls, mill speed $=80 \mathrm{rpm}$ ( $75 \%$ of critical speed), and grinding time $=15$ minutes. The number and size of balls were as follows: 60 balls of size $1.5 \mathrm{~cm}, 23$ balls of size $2.5 \mathrm{~cm}$, and 8 balls of size $3.5 \mathrm{~cm}$. Representative weights of crushing and grinding products of each sample were prepared and then sieved for the determination of the particle size distributions.

Specimens were tested for compressive strength by using a universal testing machine. The tested specimens were cubes of $3 \mathrm{~cm}$ sides after drying in an oven at 105 ${ }^{0} \mathrm{C}$ for 24 hours. Specimens of $7 * 7 * 2 \mathrm{~cm}$ dimensions were prepared for each bulk sample to determine the abrasion of the different studied granites. The specimens were surface finished to obtain parallel and smooth faces. An abrasion substance of washed sand of size $(-630+500) \mu \mathrm{m}$ was being fed for each test specimen. The machine was automatically stopped after the abrasion disc has reached 290 revolutions under a constant load of $18 \mathrm{~kg}$. The abrasion of the tested rock was calculated as the ratio of loss in weight to the cross sectional area of the tested specimen in $\mathrm{gm} / \mathrm{cm}^{2}[16]$.

Samples weighing $5 \mathrm{gm}$ were used to estimate the true density of each tested material by using a density bottle of $25 \mathrm{~cm}^{3}$ capacity.

\section{RESULTS AND DISCUSSIONS}

As discussed above, the samples understudy were classified microscopically and according to their compositions as different types of granite, i.e. diorite, tonalite, 
monzogranite and granodiorite, respectively. It was found that the main constituents of samples are plagioclase, quartz, and orthoclase. Fig. 3 shows the composition percentages of these minerals in the different samples understudy. From this figure, it can be illustrated that the percent of quartz in the samples increased from diorite, tonalite, monzogranite, to granodiorite. These data are also tabulated in Table 1.

Fig. 3 shows that monzogranite has the lowest percent of plagioclase and highest percent of orthoclase while tonalite has the highest percent of plagioclase and lowest percent of orthoclase with a moderate percents of plagioclase and orthoclase in diorite and granodiorite.

The cumulative weight distributions undersize $\mathrm{F}(\mathrm{x})$ versus particle size $\mathrm{x}$, of different bulk samples after crushing and grinding processes, were represented in Figures 4 and 5, respectively. From these figures, it can be revealed that different samples have different distributions of different particle sizes. This conclusion was obtained with both crushing and grinding processes.

In this research, the median $\left(\mathrm{x}_{50}\right)$ and mean particle size distribution (MPSD) were used as measures for evaluation of crushing and grinding processes of different samples. These measures are determined from Rosin-Rammler model as follows [17]:

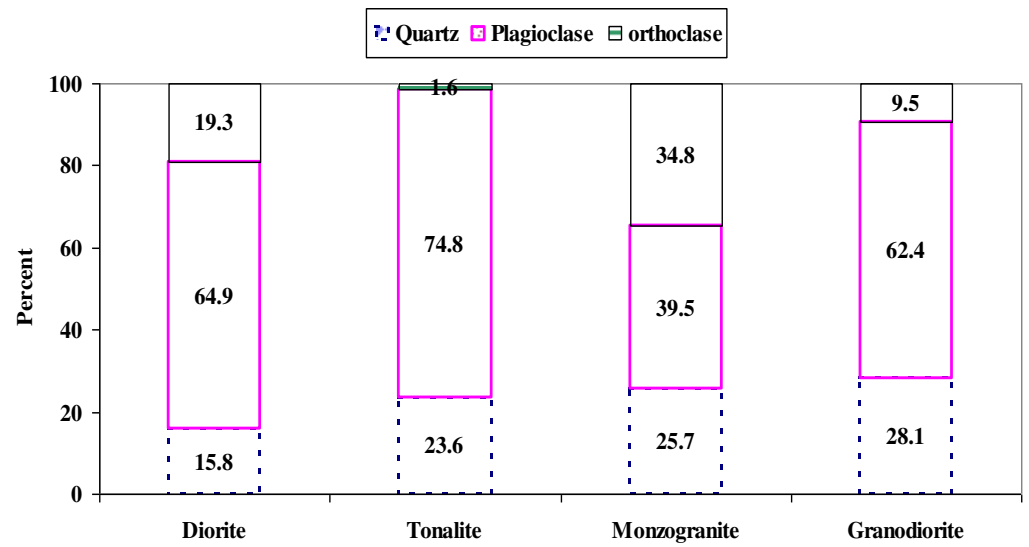

Fig. 3: Compositions of minerals in the different granites

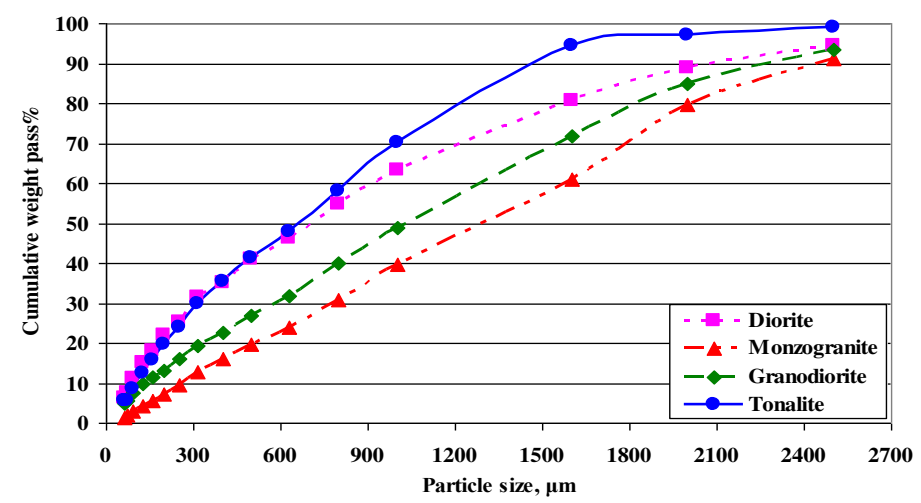

Fig. 4: Particle size distributions of different samples after crushing process 


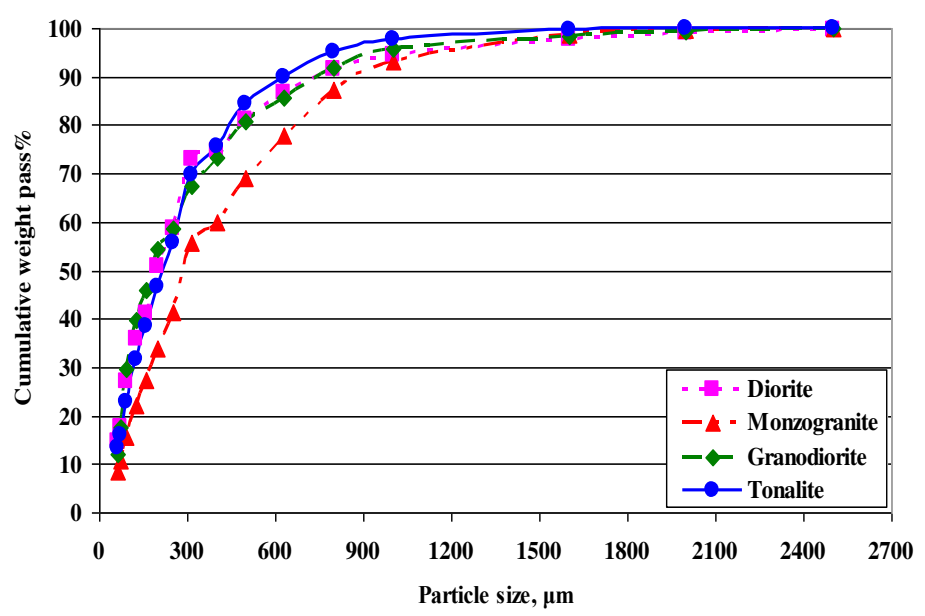

Fig. 5: Particle size distributions of different samples after grinding process

$$
\begin{gathered}
x_{50}=c[-\operatorname{Ln}(0.5)]^{(1 / m)} \\
M P S D=c \exp [0.0813298-(0.0607635 m)+(1.3431264 / \sqrt{m}) \\
-(1.0604682 \operatorname{Ln}(m) / m)-(1.3636892 / m)]
\end{gathered}
$$

A summary of the values of Rosin-Rammler model parameters, $\mathrm{x}_{50}$, MPSD, as well as the corresponding correlation coefficients of the best fit straight lines of jaw crusher discharge and ball mill product of different types of granites are tabulated in Tables $2 \mathrm{a}$ and $2 \mathrm{~b}$, respectively. From the corresponding correlation coefficients, it can be deduced that the RR model displayed a very good representation for all samples understudy.

Table 2a: The values of Rosin-Rammler model constants, $\mathrm{x}_{50}$, and MPSD of jaw crusher discharge of different granites

\begin{tabular}{|l|c|c|c|c|c|}
\hline \multicolumn{1}{|c|}{ Material } & $\mathbf{c}, \boldsymbol{\mu \mathbf { m }}$ & $\mathbf{M}$ & $\mathbf{R}^{\mathbf{2}}$ & $\mathbf{x}_{\mathbf{5 0}, \boldsymbol{\mu \mathbf { m }}}$ & $\begin{array}{c}\text { MPSD(arith), } \\
\boldsymbol{\mu m}\end{array}$ \\
\hline Diorite & 926.21 & 0.96021 & 0.99419 & 632.32 & 943.32 \\
\hline Tonalite & 760.77 & 1.17254 & 0.99227 & 556.54 & 718.96 \\
\hline Monzogranite & 1530.08 & 1.28874 & 0.99452 & 1151.34 & 1411.40 \\
\hline Granodiorite & 1306.63 & 1.01598 & 0.98295 & 910.92 & 1297.94 \\
\hline
\end{tabular}

Table 2b: The values of Rosin-Rammler model constants, $\mathrm{x}_{50}$, and MPSD of ball mill product of different granites

\begin{tabular}{|l|c|c|c|c|c|}
\hline \multicolumn{1}{|c|}{ Material } & $\mathbf{c}, \boldsymbol{\mu m}$ & $\mathbf{M}$ & $\mathbf{R}^{\mathbf{2}}$ & $\mathbf{x}_{\mathbf{5 0}, \boldsymbol{\mu m}}$ & $\begin{array}{c}\text { MPSD(arith), } \\
\boldsymbol{\mu m}\end{array}$ \\
\hline Diorite & 323.83 & 0.92235 & 0.97732 & 217.65 & 336.46 \\
\hline Tonalite & 305.85 & 1.13659 & 0.99596 & 221.55 & 291.77 \\
\hline Monzogranite & 437.88 & 1.14930 & 0.99647 & 318.31 & 416.28 \\
\hline Granodiorite & 313.03 & 0.95276 & 0.97293 & 213.07 & 320.00 \\
\hline
\end{tabular}


Fig. 6 illustrates the comparison of the values of median $\left(\mathrm{x}_{50}\right)$, as well as, mean particle size distribution (MPSD) for different granite samples obtained from crushing processes. These values are also tabulated in Table 2a.

From this figure, it can be revealed that there are clear differences between the values of $\mathrm{x}_{50}$ and MPSD of different samples resulted from crushing process. It can be also shown that tonalite sample has the lowest values of $x_{50}$ and MPSD, i.e. tonalite has more fracturing than the other samples. On the other hand, monzogranite has the highest values of $\mathrm{x}_{50}$ and MPSD. This means that monzogranite has the lowest fracturing compared with other samples.

The highest fracturing of tonalite may be attributed to the low percent of orthoclase and the high percent of plagioclase in the sample. On the other hand, the lowest crushing of monzogranite may be attributed to the high percent of orthoclase and low percent of plagioclase in the sample. From Fig. 6, it can be also found that there are no significant differences between the quartz percent into the two samples. This means that the percent of quartz has no significant effect on the crushing of tonalite and monzogranite.

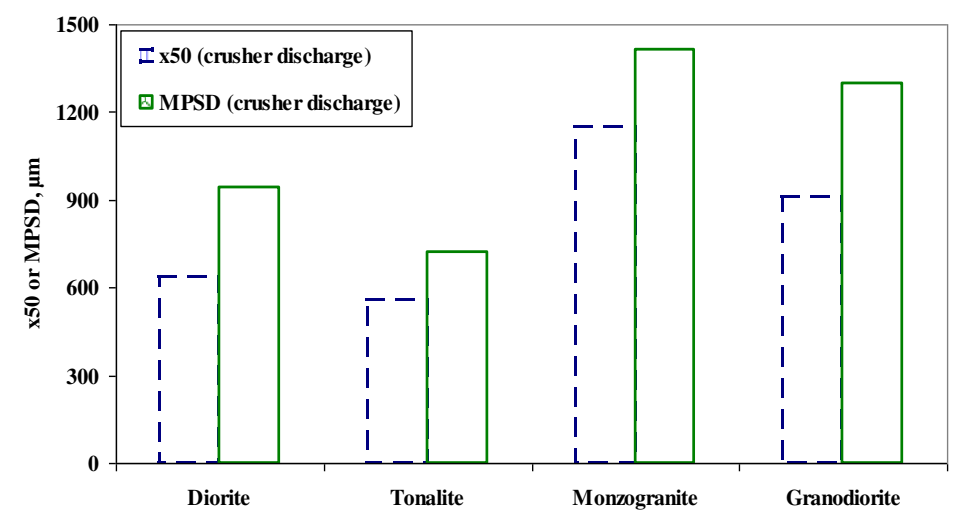

Fig. 6: The values of $x_{50}$ and MPSD of different granites after crushing processes

It can be cleared from Fig. 6 that there is a direct relationship between the percent of plagioclase and fracturing, i.e. crushing increased from monzogranite through granodiorite, diorite to tonalite as the plagioclase percent increased.

Comparison of the values of $\mathrm{x}_{50}$ and MPSD of diorite and granodiorite in Fig. 6 revealed that the percent of quartz has an effect on the crushing behavior of these two materials. Although the difference in quartz percent did not exceed $12.3 \%$, the difference in their values of $\mathrm{x}_{50}$ was about $278.6 \mu \mathrm{m}$ (36.1). This difference reached to $354.6 \mu \mathrm{m}(31.6 \%)$ between their values of MPSD.

Figure 7 reveals the comparison of the values of $\mathrm{x}_{50}$, as well as, MPSD for samples understudy resulted from grinding processes. These values are listed also in Table 2b. From this figure, it can be illustrated that there are clear differences between the values of MPSD of different samples obtained from grinding process. It can be also shown that tonalite sample has the lowest value of MPSD, i.e. tonalite has higher fineness than the other samples. On the other hand, monzogranite has the highest value of MPSD. This means that monzogranite has the lowest grinding ability compared with other samples. The percent of quartz into tonalite and monzogranite may be the 
same. Hence, the quartz percent has no effect onto the grinding process of these two materials. The highest grinding of tonalite may be attributed to the high percent of plagioclase in the sample. On the other hand, the lowest grinding of monzogranite may be attributed to the low percent of plagioclase in the sample. Compared the values of $\mathrm{x}_{50}$ for different samples assured the above interpretation of the results where monzogranite has the highest value of this measure, i.e. monzogranite has the lowest grinding.

Comparison of the values of $\mathrm{x}_{50}$ and MPSD of diorite and granodiorite in Fig. 7 assured that the percent of quartz has no significant effect on the grinding process of these two materials. Although the difference in quartz percent reached to $12.3 \%$, the difference of their values of $\mathrm{x}_{50}$ did not exceed $4.6 \mu \mathrm{m}(2.1 \%)$. This difference reached to $16.5 \mu \mathrm{m}(5.0 \%)$ between their values of MPSD.

The previous discussion assured that the percent of quartz has no significant effect on the grinding process of all materials understudy. This may be attributed to the limited probability of impact between quartz and other components owing to low percent of quartz in different materials.

Fig. 8 illustrates the effect of compressive strength of different studied granites on their crushing and grinding processes. From this figure, it is obvious that the values of $\mathrm{x}_{50}$ and MPSD for crusher discharge and ball mill product increase with increasing the compressive strength, i.e. the comminution of different granites decrease with increasing the compressive strength. This behavior may be attributed to homogeneity of composition and the uniform grain size distribution of materials having higher compressive strength, which may lead to more difficult fracturing and grinding, due to absence of cleavages or bedding planes.

Fig. 9 shows the effect of abrasion of different granites on their crushing and grinding behavior. It is clear from this figure that the values of $\mathrm{x}_{50}$ and MPSD for crusher discharge and ball mill product decrease with increasing the abrasion, i.e. the cmminution of different granites increases with increasing the abrasion. This behavior may be due to the geological structure and strength of these rocks to wear away by the contact surface of another body that is harder.

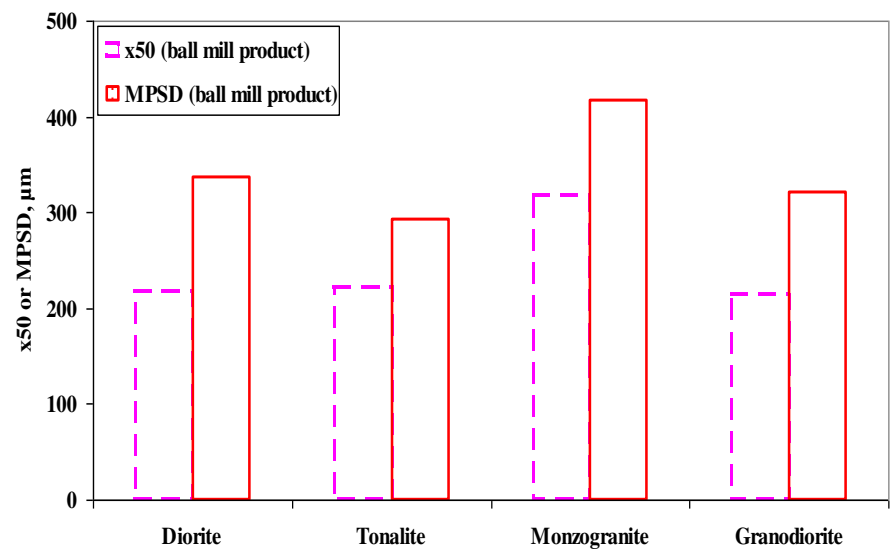

Fig. 7: The values of $x_{50}$ and MPSD of different granites after grinding processes 


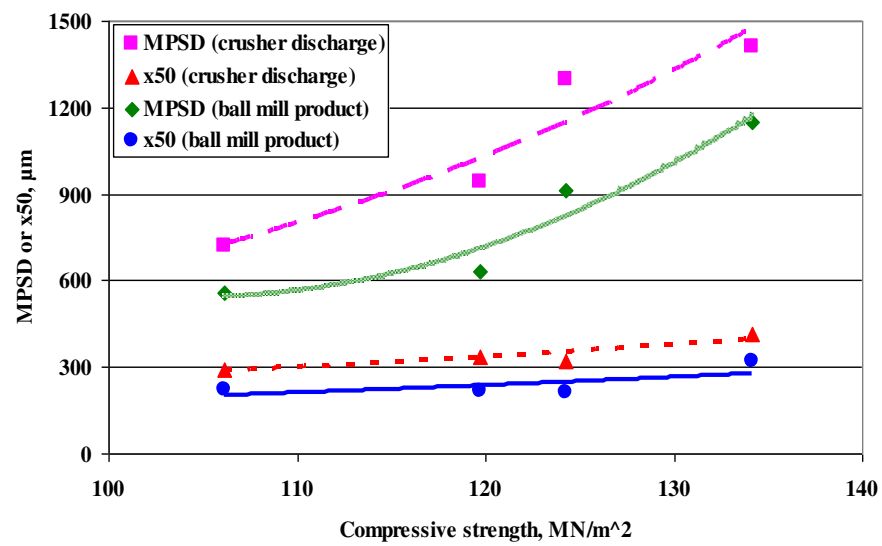

Fig. 8: Effect of compressive strength of different studied granites on their crushing and grinding processes

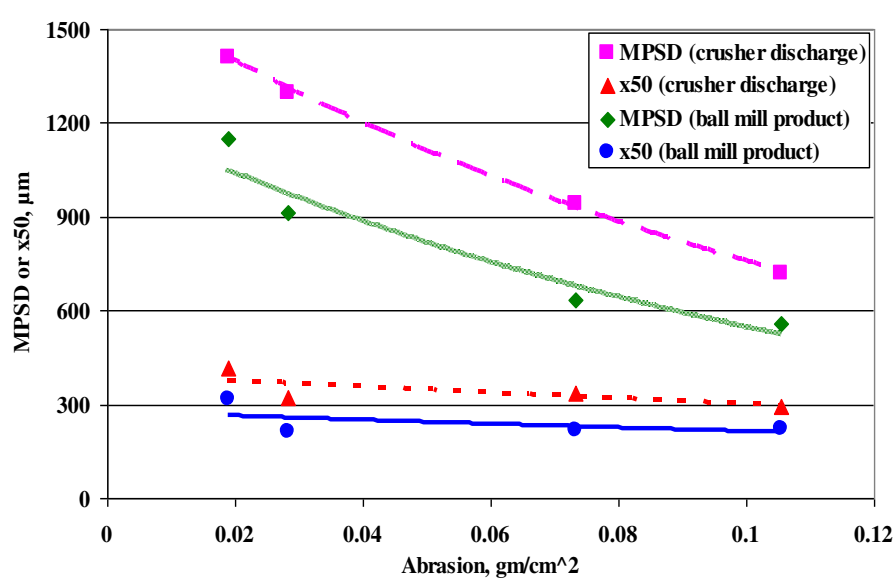

Fig. 9: Effect of abrasion of different studied granites on their crushing and grinding processes

Table 3: The compressive strength, abrasion, and density of different granites

\begin{tabular}{|l|c|c|c|}
\hline \multicolumn{1}{|c|}{ Material } & $\begin{array}{c}\text { Compressive } \\
\text { strength, } \\
\mathbf{M N}_{\mathbf{m}} \mathbf{2}^{\mathbf{2}}\end{array}$ & $\begin{array}{c}\text { Abrasion, } \\
\mathbf{g m} / \mathbf{c m}^{\mathbf{2}}\end{array}$ & $\begin{array}{c}\text { Density, } \\
\mathbf{g m} / \mathbf{c m}^{\mathbf{3}}\end{array}$ \\
\hline Diorite & 134.2 & 0.0190 & 2.51 \\
\hline Tonalite & 124.3 & 0.0284 & 2.55 \\
\hline Monzogranite & 119.7 & 0.0733 & 2.68 \\
\hline Granodiorite & 106.1 & 0.1055 & 2.61 \\
\hline
\end{tabular}

\section{CONCLUSIONS}

1. The samples understudy were classified, according to their compositions, as different types of granite, i.e. diorite, tonalite, monzogranite and granodiorite. The main constituents of samples were plagioclase, quartz, and orthoclase. 
2. Tonalite had the highest comminution characteristics of the studied samples, while monzogranite had the lowest.

3. Crushing and grinding of samples increased from monzogranite through granodiorite, diorite to tonalite as the plagioclase percent increased.

4. The quartz percent had no effect on the crushing or grinding processes of tonalite and monzogranite.

5. Quartz had a great effect on the crushing of diorite and granodiorite. Although the difference in quartz percent did not exceed $12.3 \%$, the difference in their values of $\mathrm{x}_{50}$ reached to $278.6 \mu \mathrm{m}(36.1 \%)$. This difference was about $354.6 \mu \mathrm{m}(31.6 \%)$ between their values of MPSD.

6. The quartz percent had no clear effect on the grinding of diorite and granodiorite. Although the difference in quartz percent reached to $12.3 \%$, the difference in their values of $\mathrm{x}_{50}$ did not exceed $4.6 \mu \mathrm{m}(2.1 \%)$. This difference was about $16.5 \mu \mathrm{m}$ $(5.0 \%)$ between their values of MPSD.

7. Quartz percent had no great effect on the grinding process of all materials understudy.

8. The crushing and grinding of different studied granites decreased with increasing the compressive strength and decreasing the abrasion.

\section{REFERENCES}

[1] Marabini, A.M., Plescia, P., Maccari, D., Burragato, F., Pelino, M., "New materials from industrial and mining wastes: glass-ceramics and glass- and rock-wool fiber", Int. J. Mineral Process., Vol. 53, Issues 1-2, pp. 121-134, Feb., 1998.

[2] Amarante, M.M., Botelho de Sousa, A., Machado Leite, M., "Processing a spodumene ore to obtain lithium concentrates for addition to glass and ceramic bodies", Minerals Engineering, Vol. 12, Issue 4, pp. 433-436, Apr., 1999.

[3] Styriakova, I., Styriak, I., Malachovsky, P., Lovas, M., "Biological, chemical and electromagnetic treatment of three types of feldspar raw materials", Minerals Engineering, Vol. 19, pp. 348-354, 2006.

[4] Akaad, M.K., EL-Ramly, M.F., "Geological history and classification of the basement rocks of Central Eastern Desert of Egypt", Geological Survey, Cairo, Egypt, Vol. 9, pp. 1-24, 1960.

[5] El-Shazly, E.M., "On the classification of the Precambrian and other rocks of magmatic affiliation in Egypt, U.A.R.", Proceedings $22^{\text {nd }}$, International Geological Congress, New Delhi, India, Vol. 10, pp. 88-101, 1964.

[6] El-Gaby, S., Habib, M.E., "Geology of the area South West of Port Safaga, with special emphasis on the granitic rocks, Eastern Desert, Egypt", Annuals Geological Survey, Egypt, Vol. 12, pp.47-71, 1982.

[7] El-Shatoury, H.M., Mostafa, M.E., Nasr, E.F., "Granites and granitoid rocks in Egypt, a statistical approach of classification" Chemie der Erde, Vol. 43, pp. 83$111,1984$.

[8] El-Gaby, S., List, F.K., Tehrani, R., "The basement complex of the Eastern Desert and Sinai" In: R. Said (ed.), the geology of Egypt, Balkema, Rotterdam, Brookfield, pp. 115-134, 1990. 
[9] Xu, X., "Experimental study on temperatures and energy partition at the diamondgranite interface in grinding", Tribology International, Vol. 34, Issue 6, pp. 419426, June, 2001.

[10] Pintaude, G., Tschiptschin, A.P., Tanaka, D.K., Sinatora, A., "The particle size effect on abrasive wear of high-chromium white cast iron mill balls", Wear, Vol. 250, Issues 1-12, pp. 66-70, Oct., 2001.

[11] Karaguzel, C., Gulgonul, I., Demir, C., Cinar, M., Celik, M.S., "Concentration of K-feldspar from a pegmatitic feldspar ore by flotation", Int. J. Mineral Process., Vol. 81, Issue 2, pp. 122-132, Nov., 2006.

[12] Michaux, S., Djordjevic, N., "Influence of explosive energy on the strength of the rock fragments and SAG mill throughput", Minerals Engineering, Vol. 18, Issue 4, pp. 439-448, Apr., 2005.

[13] Campbell, P., Vorster, W., Merchant, A.J., Rowson, N.A., "The use of the three point bend test to quantify the effects of thermal pre-treatment on rock strength", Minerals Engineering, Vol. 14, Issue 8, pp. 901-904, Aug., 2001.

[14] Lu, D., Zhou, X., Xu, Z., Lan, X., Tang, M., Fournier, B., "Evaluation of laboratory test method for determining the potential alkali contribution from aggregate and the ASR safety of the Three-Gorges dam concrete", Cement and Concrete Research, Vol. 36, Issue 6, pp. 1157-1165, June, 2006.

[15] Streckeisen, A., "A classification of common igneous rocks by means of their chemical composition", A provisional attemp., N., Jb., Miner. Monatshfte, pp. 1$15,1976$.

[16] Conca, J.L., Cubba, R., "Abrasion resistance hardness testing of rocks materials", Int. J. Rock Mech. Min. Sci.\&Geomech. Abstr., Vol. 23, No. 2, pp. 141-149, April, 1986.

[17] Ahmed, M.M., Ahmed, S.S., "A comparison study to determine the mean of particle size distribution for truthful characterization of environmental data (part 1)", J. Eng. Sci., Assiut University, Vol. 36, Issue 1, pp. 147-166, Jan., 2008.

\section{دراسة نواتج التكسير و الطحن لعينات من صخور الجرانيت بجنوب الصحراء الثرقية-

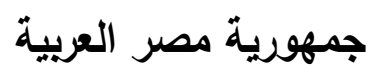

صخور الجرانيت تعتبر من أهم الصخور النارية التي تستغل للزينة من خـلال الأحجام الكبيرة و عند استخراج هذه الصخور ينتج عنها أجزاء صغيرة الحجم لا تستغل ولكن بالتكسير والطحن لهذه الأجزاء يمكن أن تستخدم في بعض التطبيقات الصناعية منل صناعة السيراميك و الزجاج وكذلك معدن الفلسبار وهو المكون الرئيسي لصخور الجرانيت يدخل في هذه الصناعات.

و الهدف مـن هذا البحـث هـو دراسـة و مقارنـة نـواتج التكسير و الطحن لعينـات مختلفـة مـن صـور الجرانيت نم الحصول عليها من عدة أماكن بجنوب الصحراء الشرقية.

العينات التي تم دراستها صنفوا وفقا للتركيب المعدني للجرانيت من حيث نسب الفلسبار (البلاجيوكليز و الأورثثوكليز) والكـوارتز إلـي أربـع أنـواع مختلفـة و هـي التوناليـت والجرانودايوربـت والمونزوجرانيـت 
وقد أظهرت النتائج أن التوناليت هو أكثر الأنواع قابلية للتكسير بينما كان المونزوجرانيت هو اقلهم قابلية

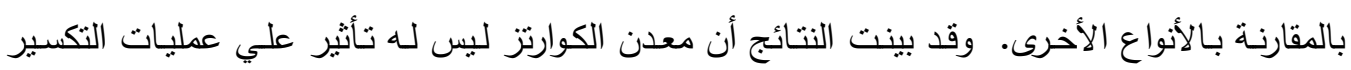

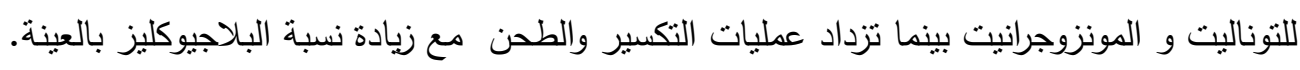

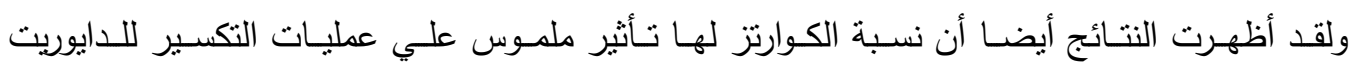

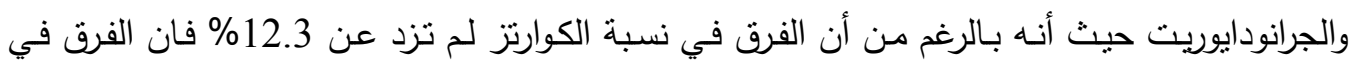

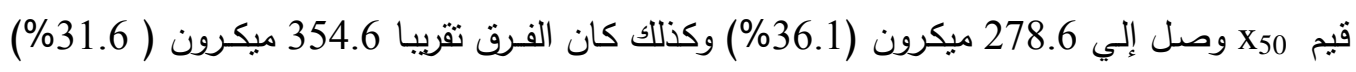
في قيم MPSD. ولقد أظهرت النتائج أن نسبة الكوارتز ليس لها تأثير ملموس علي عمليات الطحن لهاتين العينتين حيث وجد أن الفرق في قيم X50 وصل إلي 4.6 ميكرون فقط (2.1\%) وكذللك كان الفرق تقريبا 16.5ميكرون

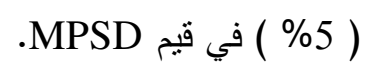
كما أظهرت النتائج أن نسبة الكوارتز ليس لها تأثير واضح علي عمليات الطحن لكل العينات التي تم

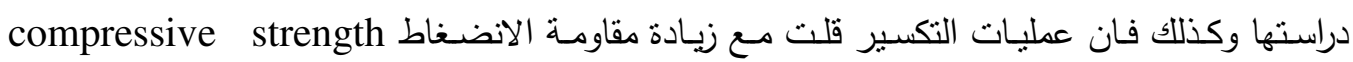
ونقص البرى Abrasion دلعينات المختلفة. 